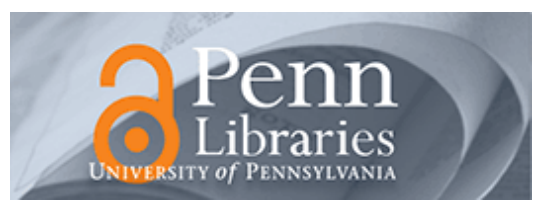

\title{
Bellwether Magazine
}

Volume 1

Number 15 Summer 1985

Article 10

Summer 1985

\section{Admissions and Financial Aid}

John E. Martin

University of Pennsylvania

Follow this and additional works at: https://repository.upenn.edu/bellwether

\section{Recommended Citation}

Martin, John E. (1985) "Admissions and Financial Aid," Bellwether Magazine: Vol. 1 : No. 15 , Article 10.

Available at: https://repository.upenn.edu/bellwether/vol1/iss15/10

This paper is posted at ScholarlyCommons. https://repository.upenn.edu/bellwether/vol1/iss15/10

For more information, please contact repository@pobox.upenn.edu. 


\section{Admissions and Financial Aid}

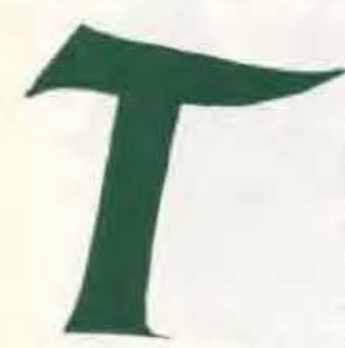

lis year the School of Veterinary Medicine graduated its 10() th class. Four years ago the students in this class had been successful candidates in a highly competilive admissions process. They then

embarticel on an educational program which demands rigorous. full-time application. However. 60 percent of the students also had to contend with the emotional and time-consuming problem of linancing their educations.

In a real sense, admission to the School and Financial Aid have sume interlocking conditions. Most students applsing for admission to Penn's Veterinary School have a strong desire to altend this School. Last year tuition for Pennsylvania tesidents and contract students was $\$ 9,630$. The median tuition for all U.S Veterinary Schools was \$3.170. Many students are linding it increasingly difficult to meet the high cost of veterinary medical education at Penn. Our School oflers financial aid to those students who yualify but because of our high tuition. and because most of our aid is in the form of loans, applicants foresee a gloomy financial sizuation looming in the ir future.

The fact that we still have more applieations than any other veterinary school in the United States speaks very highly of our reputation. but our unlavorable position on tuition and linancial aid may make it more diflicult to altract the very best students.

Following is a bricl discussion of the admissions and linancial aid situations and a consideration of some of the sleps which the School is taking to improve the picture.

\section{Admissions}

The admissions procedure is one of the most difficult and time-consuming functions in the School of Veterinary Medicine. Decisions concerning the admissions of new students rest with the Admission Committee. chaired by Dr. Joseph F. Shelley. Associate Dean for Admissions and Student Affairs. In 1985, there were 626 applicants for 109 places: approximately 310 applicants were inlerviewed by the Admissions Commillee.

Students admitted to the School come from one of several categories: Pennsylvanial residents. outof-state residents and contract students. Penn: Veterinary School has the second highest tuition of any vcierinary school in the country. and we are increasingly concerned about this disparity. Not only are we interested in yuality students. we also wish to maintain a diversity in classes based on such things as socin-economic background, major carreer interests. geographic distribution and racia and ethnic origin. With our high tuition and the drying-up of sources for financial aid. we are dceply concerned that financial status may become an overriding factor in students applying here and becoming matriculants.

\section{Student Financial}

\section{Aid Program}

Financial aid. unforturiately. has bercome a major feature of academic life for ahout 60 percent of students in the Veterinary School. Unfortunate in that it contributes signilicantly to the stress felt by many students in their rigorous cducational program and it is the source of a substantial debt load accumulated by the lime of graduation.
Eligibility for linanctal a id at the Veterinary School is based strictly on the demonstration of need by the studerit. Nieed is established by a careful scrutiny of a student's and his/her familys financial situation.

Once a need is documented. the student becomes eligible lor vatious types of aid. At the Vecterinary School almost all financial aid is in the form of loans: we have only limited scholarship funds.

The lirst $\$ 5.000$ of any need must to met with a Guaranteed Student Loan (CSL) which the student obtains from a participating bank. This loan is at 8 percent interest which is paid by the lederal government while the student is in school. If a student's need exceeds $\$ 5.010$ he she hecomes eligible for other federal lunds which are administered by the University. The two primary loan sources in this category are the Nitional Direct Student Loan (NDSL) and the Health Prolessions Loan (HPL). The NDSL is al 5 percent interest and the HPL imterest is 9 percent.

Students may also yualify for aid through the Work-Study Program in which an individual is paid for work (e.g. feeding animals. Washing glassuare. typing and filing) perlor med, usually in the Veterinary School. This is a federally funded program.

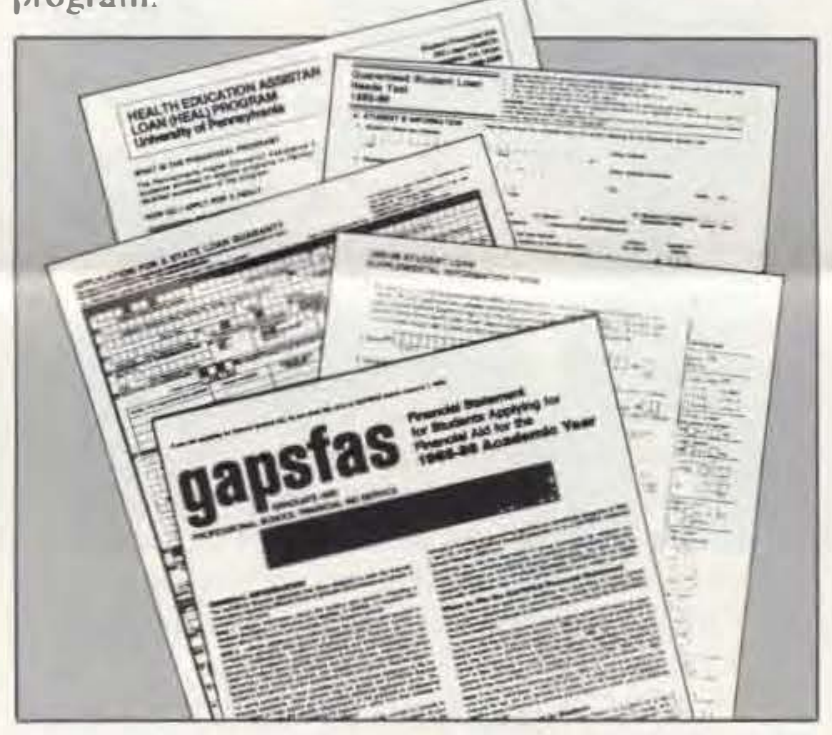

In addition to these loans and the Work-Study Program, the Velerinary School has some small loan and scholarship funds which are sel up by individuals, kennel clubs and pharmaceutical lirms.

If the entire need ol a student cannot be met through these sources. Iwo courses of action are open: (1) the student must obtain outside loans at a higher rate of inlerest. or (2) the Velerinary School subsidizes the Financial Aid Program with loan/scholarship money.

There are two types ol higher intelest loans available to our students, both of which are obtained by the student applying directly to a kender. One of these is the HEAL loan (Health Education Assistance Loan) and the other is the PLUS loan (Parental Loans to Assist Students). The PLUS loan is currently at 12 percent interest which must be paid while the student is in school. Interest on the HFAl. loan varies with the rate of Ireasury Bills (maximum rate of 91 -day T-bill plus 3.6 percent), and while it may he deferred until graduation. it begins to accrue at the time the loan is made. Recently the Pennswlvania Highter Education Assistance Agency (PHEAA) has begun to issue HEAL loans at a lesser rate of interest (maximum rate of 91-day 1 -bill minus 0.5-1.0 percent).

Most of the major loan programs hatre limits which cannot be exceeded. For example. the GSL has an annual limil of $\$ 5.000$ and an aggregate limit of \$25.00)0. including loans made in undergraduate schoot. The NDSL has all aggregate ceiling of $\$ 12,000$, including

undergraduate loans. Because of the higher cost of our educational program (increased tuition. highe costs of books and instruments) many students How reach the limit ol their NDSI eligibility by the second or third year in school. When this is the case the student must usually obtain loans at the higher interest rute.

A second major problem. also related to the higher costs of education. is that students are accumulating loan debis of staggering levels. An analysis of 51 students in the 1985 graduating class reveals loan debts from $\$ 29,30010 \$ 63.93 x$. Thus many students just beginning professiona! and lamily life (including purchase ol expensive instruments and eyuipment, a home, etc.) are faced with an almost overwhelming financial sit uation. especially when one considets that the average starting income of a vetcrinarian is about $\$ 19.500$.

If even a part of the changes proposed by the federal administration are enacted into law. we lace a sit uation in which there simply will not be enough aid money available in any form to meet students' needs as they are presently determined.

Tiwn approaches which would obviously have a greast positive impact on the gloomy linancial aid picture are to lower tuition and to create a barge endowsment fund for scholarship aid. Realistically. neither of these changes can be expected in the inumediate furure.

The Veterinary School this yeat has taken some sleps to improve the financial picture and 10 lielp alleviate some of the stress now felt by students. Dean Robert R. Marshak has direcled that scholarships of \$3.060 each be awarded to tive students in the incoming class on a meril basis. The scholarships will continue for the four vears while a student is in school and will enahle us to attract outstanding students whe might go elsewhere to school at a lower tuition.

This year the School also published a Harrdhoost ons Susekens Financial dicl which contains detailed inlormation about how need is determined, loans. repayment schedules. cte. Some of the apprehensions sluderils experience about financial aid are related to not having enough inlormation (or having litulty inlormation about the total Program. The Ilandhenth should help alleviate this.

We are presently developing a computer program which will enahle students 10 oblain information about how they may manage their loan debis for a ten year perioxl alier graduation. This program will be tailored to the individual and it will be based on a student 's anticipated situation during this ten year period (i.e. lype work. anticipated salary. family sifuation. elc.). Again. we believe that this knowled ge will help (t) lessen students* concern about their financial situation. The program will be available in the icademic: year 1985-86.

As was the case last year. the Veterinary Schuol will subsidize the Financial Aid Program for students whose demonstrated nexed is not mer with the usual sources of money. Many sludenis will need 10 obtain III:AL. Loans in 1985-86 and the School will pay interest on these so that it does not accrue while the students are in school,

Jolun E. Martin, 1/1.12 